государства. Выполнению этой задачи, на наш взгляд, соответствует трехуровневая банковская система, состоящая из Банка капитала (Инвестиционный банк), Центрального эмиссионного банка и коммерческих банков. Существуют примеры успешного сочетания промышленной и финансовой политики на основе целенаправленной стратегии государства. После войны во Франции правительственную политику осуществляли казначейство и центральный банк, являясь наиболее важными кредиторами в течение 1950-х годов. Они сыграли значимую роль в «запуске» финансовой системы и создании частного сектора. В 1960-х годах эти функции центрального банка и казначейства перешли к ряду банков и институтов кредитования. Однако влияние государства на финансово-денежную политику осталось в форме целевого перераспределения средств, в чем большую роль сыграл Кредитный национальный совет CNC.

$$
* * *
$$

1. Глазьев С. Ю. Эксперименты ценою в суверенитет // Эксперт. - 6-12 июня 2015. - № 28. - С. 34-38.

2. Долженков А. «Возрождение» пойдет по рукам // Эксперт. 29 января - 4 февраля 2018. - № 5. - С 38 39.

3. Жан Сапир. Взаимосвязь монетарной политики и экономического развития в современной Европе: проблемы и возможные решения //Проблемы прогнозирования. - 2017. - № 5. - С 3-10

4. Ивантер А. Весьма специфический бизнес // Эксперт. - 29 октября - 4 февраля 2018. - № 5. - С. $40 \neg 41$

5. Ивантер А. Синдром отмены // Эксперт. - 2-8 октября 2017. - № 40. - С. 15-20.

6. Колерова В. Детальный подход //Эксперт. 22-28 января 2018. - № 4. - С 28-30.

7. Матовников М. Олигополия как драйвер конкуренции //Эксперт. - 2018. - № 3. - С 32-37.

8. Соловьева С. В. Тенденции и перспективы развития российской банковской системы // Региональ ᄀные проблемы преобразования экономики. - 2017. - № 4. - С. 99-106.

\title{
Буянтуева С.Б.
}

\section{Управление межэтническими отношениями в Новосибирской области}

Министерство региональной политики Новосибирской области (Россия, Новосибирск)

doi:10.18411/spc-01-02-2019-11

idsp: sciencepublic-01-02-2019-11

\section{Аннотация}

Целью исследования является анализ опыта и проблем управления межэтническими отношениями в Новосибирской области, а также разработка комплексных мер по совершенствованию управления межэтническими отношениями в Новосибирской области. Основными методами исследования стали: статистический анализ, анализ документов, системный подход. В работе обозначены основные проблемы управления межэтническими отношениями в Новосибирской области, подходы к их решению и меры по совершенствованию управления межэтническими отношениями в Новосибирской области.

Ключевые слова: межэтнические отношения, этнос, нация, национальная политика, национальность

Упрочение общероссийского гражданского самосознания и духовной общности многонационального народа является одной из фундаментальных задач, стоящих перед государством. К числу ключевых вопросов национальной политики демократической России относится компетентное управление вопросами формирования и развития межэтнических отношений.

На территории Новосибирской области проводится планомерная работа по реализации государственной национальной политики в сфере предупреждения 
межнациональных конфликтов, гармонизации этнорелигиозных отношений, развитию и поддержке институтов гражданского общества.

В целях гармонизации межнациональных отношений, укрепления общероссийской гражданской идентичности и этнокультурного развития народов в Российской Федерации в рамках Стратегии государственной национальной политики Российской Федерации на период до 2025 года на территории Новосибирской области реализуется Комплексный план действий по гармонизации межэтнических отношений и реализации Стратегии государственной национальной политики Российской Федерации на период до 2025 года в Новосибирской области на 2016-2018 годы, утвержденный распоряжением Правительства Новосибирской области от 23.08.2016 № 310-рп, содержащий 55 мероприятий по 12 направлениям.

Новосибирская область всегда отличалась многонациональным составом и многоконфессиональностью, на территории которой проживают представители более 180 национальностей. Область среди регионов Сибирского федерального округа на протяжении десяти лет является наиболее притягательной территорией въезда как для мигрантов, переселяющихся на постоянное место жительство, так и для иностранных трудовых мигрантов.

По данным Всероссийской переписи населения 2010 года по сравнению с данными 2002 года в Новосибирской области национальная картина области не претерпела значительных изменений: доля русских составила 93,1 \% (в 2002 году - 93,0 \%) от числа указавших этническую принадлежность. Статистика показывает, что представителей четырех наиболее многочисленных народов в Новосибирской области стало меньше: русских - на 138302 человека (всего 2365845), немцев - на 16351 человек (всего 30924), украинцев - на 11697 человек (всего 22098) и татар - на 3716 человек (всего 24158).

В то же время наблюдается увеличение количества узбеков, которые заняли пятое место по численности среди этнических общностей области - 12655 человек (в 2002 году - 2047 человек, 15-е место), таджиков - 10054 человека (в 2002 году - 2784 человека), киргизов - 6505 человек (в 2002 году - 1423 человека). Кроме того, несколько выросла численность выходцев с Кавказа: 9508 армян (в 2002 году - 7850 человек) и 8008 азербайджанцев (в 2002 году - 7366 человек). Показательно, что выходцы из Средней Азии активно селятся именно в городе Новосибирске.

По данным статистиков, значительно увеличилось количество людей, не указавших свою этническую принадлежность: в 2002 году - 391 человек, а в 2010 году - 124859 человек.

Сегодня социальная среда Новосибирской области имеет мультикультурный и полиэтничный характер. При этом в городе Новосибирске существуют территории компактного проживания мигрантов, - это районы юго-западной и восточной части города, окраины и зоны, прилегающие к рынкам, а также частный сектор, расположенный вдоль железной дороги и малых городских рек. Эти территории заселены представителями Азербайджана, Узбекистана, Таджикистана, Киргизии и т. д.

На сегодняшний день в области по данным Главного управления Министерства юстиции России по Новосибирской области зарегистрировано 81 общественная национальная организация, представляющая 27 национальностей: русские, немцы, татары, украинцы, узбеки, казахи, таджики, армяне, азербайджанцы, киргизы, белорусы, евреи, поляки, китайцы, езиды, корейцы, молдаване, хакасы, буряты, осетины, уйгуры, дагестанцы, грузины, греки, туркмены, мордва, монголы.

На территории региона действуют 33 национально-культурных автономий (8 региональных и 25 местных). Кроме того, на территории осуществляют свою деятельность не зарегистрированные общественные организации - финская, удмуртская, якутская. 
Таким образом, целью исследования явился анализ опыта и проблем управления межэтническими отношениями в Новосибирской области, а также разработка комплексных мер по совершенствованию управления межэтническими отношениями в Новосибирской области.

Объектом исследования являются межэтнические отношения, а предметом содержание и специфика управления межэтническими отношениями в Новосибирской области.

Главным результатом реализации мероприятий, направленных на укрепление мира и согласия в Новосибирской области стала выработка единых подходов к решению вопросов в сфере государственной национальной политики и сохранение стабильной межнациональной ситуации, что подтверждают проведенные социологические исследования в 2018 году, которые являются важным маркером анализа работы в сфере этнических отношений. Они призваны проанализировать текущую ситуацию, оценить эффективность принимаемых мер и определить возможности для снижения угрозы межнациональных конфликтов.

В 2018 году социологические исследования показали прирост показателей, отражающих толерантный характер отношений между людьми разных национальностей. Большинство опрошенных жителей области (77 \% в 2018 году, 72 \% в 2017 году, 68 \% в 2016 году) полагают, что в их городах (посёлках) сложились добрососедские отношения между людьми разных национальностей. $9 \%$ считает, что улучшились, 68 \% - остались хорошими.

84 \% опрошенных жителей области оценили межнациональные отношения, сложившиеся в их населенном пункте, как бесконфликтные, в том числе 20 \% как доброжелательные. Такой же показатель (84 \% позитивных оценок) зафиксирован в оценке межконфессиональных отношений в регионе.

В отношении собственной толерантности оценки еще выше (87\% участников опроса сказали, что не испытывают раздражения и неприязни по отношению к людям другой национальности (в 2017 году - 85\%, в 2016 году - 83 \%).

Впервые повысился показатель оценки работы региональных и местных властей в сфере межнациональных отношений. За последний год доля удовлетворенных жителей выросла с 40 \% до 53 \%. По мнению новосибирцев, работа властей должна включать как мероприятия по ассимиляции трудовых мигрантов, так и по адаптации коренных жителей (особенно молодежи) к жизни в мультинациональной среде.

В рамках работы по недопущению проявлений национального и религиозного экстремизма, предупреждению межнациональных конфликтов и реализации государственной национальной политики по гармонизации межэтнических отношений принимаются следующие меры:

- регулярное взаимодействие с национальными общественными организациями и авторитетными лидерами по профилактике проявлений религиозного и национального экстремизма;

- $\quad$ проведение заседаний Совета при Губернаторе Новосибирской области по межнациональным отношениям;

- мероприятия по сохранению этнокультурного многообразия области;

- взаимодействие с исполнительными органами государственной и муниципальной власти, территориальными подразделениями федеральных исполнительных органов власти, институтами гражданского общества по вопросам реализации государственной национальной политики, в том числе предупреждению ксенофобии, экстремизма и терроризма в сфере межнациональных отношений;

- проведение рабочих встреч с представителями духовенства, национальных диаспор и организаций по вопросам объединения усилий 
в деле противодействия экстремизму и духовно-нравственного оздоровления общества;

- федеральная система мониторинга состояния межнациональных и межконфессиональных отношений и раннего предупреждения конфликтных ситуаций в Новосибирской области;

- телефон «Прямой линии» по межнациональным отношениям;

- наряду с автоматической системой мониторинга министерством региональной политики Новосибирской области ежегодно проводятся комплексные социологические исследования. В текущем году в рамках государственной программы «Укрепление единства российской нации и этнокультурное развитие народов, проживающих на территории Новосибирской области на 2015-2020 годы» проведены социологические исследования «Эффективность государственной национальной политики, изучение состояния межнациональных и межконфессиональных отношений и раннего предупреждения конфликтных ситуаций в Новосибирской области».

Таким образом, в работе обозначены основные проблемы управления межэтническими отношениями в Новосибирской области, подходы к их решению и меры по совершенствованию управления межэтническими отношениями в Новосибирской области. На данный момент в целом в результате мониторинга состояния межнациональных отношений в Новосибирской области и анализа проводимых мероприятий следует отметить незначительное улучшение межнациональных отношений. Сохраняется напряжение по отношению к мигрантам среди потребителей медицинских, образовательных услуг - в связи с повышением нагрузки на образовательные и медицинские учреждения в отдельных районах.

$$
* * *
$$

1. Постановление Правительства Новосибирской области от 08.06.2015 № 216-п «О государственной программе Новосибирской области «Укрепление единства российской нации и этнокультурное развитие народов, проживающих на территории Новосибирской области, на 2015-2020 годы». [Электронный ресурс]. - Доступ из справ.-правовой системы «КонсультантПлюс»;

2. Нерусские идут - НГС.НОВОСТИ. [Электронный ресурc]. - URL.: https://news.ngs.ru/more/2174932/ 